\title{
Achieving Sustainable Development Goals. Efficiency in the Spanish Clean Water and Sanitation Sector
}

\author{
Pedro-José Martínez-Córdoba ${ }^{1}$ (D) Nicola Raimo ${ }^{2, *}$ [D , Filippo Vitolla ${ }^{2}$ and Bernardino Benito ${ }^{1}$ (i) \\ 1 Department of Accounting and Finance, Faculty of Economics and Business, \\ Regional Campus of International Excellence “Campus Mare Nostrum”, University of Murcia, \\ 30100-Espinardo (Murcia), Spain; pedrojose.martinez3@um.es (P.-J.M.-C.); benitobl@um.es (B.B.) \\ 2 Department of Economics and Management, LUM Jean Monnet University S.S. 100 km. \\ 18 70010-Casamassima (Bari), Italy; vitolla@lum.it \\ * Correspondence: raimo.phdstudent@lum.it
}

Received: 12 March 2020; Accepted: 2 April 2020; Published: 9 April 2020

\begin{abstract}
In recent years, achieving the Sustainable Development Goals (SDGs) is becoming a major challenge for local governments. This research focuses on the role of Spanish local governments in the fulfillment of SDG-6, which aims to ensure the availability and sustainable management of water and sanitation for all citizens. Specifically, this study analyses the evolution of the efficiency of Spanish local governments, and its determining factors, in the achievement of the SDG-6. The results indicate that the taxes associated with water supply and sanitation services, the private management of these services, population density, local government budget revenues, the income of the inhabitants of the municipality and the fragmentation of local governments are factors that can improve the evolution of the efficiency of Spanish local governments in achieving the SDG-6.
\end{abstract}

Keywords: Sustainable Development Goals (SDG); drinking water supply and sanitation; Malmquist index; local government; effective cost

\section{Introduction}

The year 2015 represented an important step for international sustainable development. In an inclusive, open, and transparent process, the 193 member states of the United Nations (UN) adopted the 2030 Agenda, containing 17 Sustainable Development Goals (SDGs) and 169 targets connected to them [1]. The 2030 Agenda represents a global transformative program setting a clear goal: To improve the world in order to ensure the prosperity of the planet and the people [1].

The 17 SDGs represent an action plan that integrates social, economic, and environmental aspects, being binding for developed and developing countries. The 2030 Agenda has an impact on all sections of society and also on the public sector [2]. In this context, government bodies have to respond to SDGs and actively participate in their promotion and functioning. The public sector, and in particular, local governments, plays an important role in achieving the particular SDG-6, which says: "Ensure availability and sustainable management of water and sanitation for all". In the case of Spain, the supply of drinking water is one of the most important municipal services provided by local governments. Article 26.1 of Act 7/1985 (Regulation of Competences of Local Authorities) classifies it as an essential service of general interest, and its provision is obligatory in all municipalities. In this regard, it should be noted that the term "clean water" is assimilated with uncontaminated water, and therefore, "drinking water". In this sense, this study will use the terms "clean water" and "drinking water" interchangeably.

The aim of our research is to analyze the evolution of the efficiency in public services referred to in SDG-6, and its determinants, by Spanish local governments. This study is part of the ongoing 
debate on the efficiency in the management of water resources, which has become even more relevant with Agenda 2030 and, in particular, in relation to SDG-6. In this regard, measuring the evolution of the efficiency in the provision of water supply and sanitation services, and identifying how it can be improved to achieve SDG-6, is a further step towards the prosperity of the planet and people. However, despite the relevance of the topic, previous studies have investigated the efficiency of local governments in the provision of drinking water through Data Envelopment Analysis (DEA) and regression models. These approaches do not allow the measurement of inter-annual efficiency. In light of this, there is a clear need for more advanced methodologies capable of enabling a better understanding of the phenomenon. In this regard, our study aims to fill this important gap by using a different approach, represented by the Malmquist index (inter-annual evolution of efficiency) and a truncated regression model. In fact, this methodology allows an assessment of the inter-annual evolution of the efficiency of Spanish local governments in relation to the resources used to achieve SDG-6.

Regarding the analysis of the determinants, this study investigates the impact of the characteristics of the service and the demographic, economic, and political factors of the municipality represented by taxes, type of management, population density, level of tourism, citizens' income, political ideology and political strength of the government.

The structure of this study is organized as follows. After this introduction, we review the literature analyzing the relevance of SDGs and the determinants of efficiency in water supply and sanitation. Section 3 presents the methodology, referring to the sample, variables, and econometric model. Section 4 presents the results and discussion. Finally, in Section 5, we draw the main conclusions and implications of our findings, the limitations of the study, and the directions for further research.

\section{Literature Review}

The public sector is considered a manager with regard to environmental and social issues. Its main objective is implementing public policies and promoting social welfare [3]. The public sector has a more important role and greater responsibilities than the corporate sector in environmental and social issues [4]. It is a fact that companies mainly pursue the objective of maximizing shareholder value, while the public sector attends to those essential services for the life of the citizen and in the achievement of SDGs [2-5].

This circumstance is considerably increasing the attention towards the improvement of the efficiency and effectiveness of the public sector's actions and policies. Increased demand for public services and the limited local government revenues are forcing the latter to improve efficiency. The relevance of the issue of public sector efficiency has led to a considerable increase in academic contributions. In this regard, Narbón-Perpiñá and De Witte [6,7] summarized and classified all the studies published between 1990 and 2016 on the topic of the efficiency of local governments.

The efficiency of local governments has been analyzed in relation to different public services (e.g., waste collection, drinking water supply, street lighting, and transport). In addition, other aspects have been evaluated such as: The extent of SDGs at the local level [8], the problem of water scarcity in reference to SDGs [9], the analysis of a part of SDG-6 [10], the indicators for evaluating drinking water, sanitation, and hygiene (WASH) related to SDG-6 [11], and the total service gap in reference to target two of SDG-6 [12]. Among them, our study focuses on the SDG-6 from the perspective of Spanish local governments, considering that access to drinking water represents a fundamental need for the citizens [13]. In this perspective, policymakers are responsible not only for the presence of water resources that can satisfy all citizens but also for the improvement of well-being concerning the use of these resources [14]. To this end, the spread of more sophisticated analysis methods, access to more information, and new legislation have allowed the study of efficiency in the management of water resources at the local level.

Refs [15-19] provide a detailed literature review on the topic of efficiency in water resource management. Moreover, some studies are also focused on Spain [20-25]. The inefficiencies associated with restrictions on the use of water, investments, and current price agreements lead to problems 
connected to the deterioration of water quality and the infrastructures, and the increase in access costs [16] affecting the citizens' well-being. On the contrary, a high level of efficiency in the management of water resources should offer several benefits to citizens, also in terms of a lower cost of access to these resources [17].

See [15] classified studies on the issue of efficiency in the management of water resources into three different categories: The contributions that aim to analyze and compare the efficiency of public and private services, other contributions that, through Stochastic Frontier Analysis (SFA), estimate the economies of scale, density, and scope, and finally, those contributions that, through Data Envelopment Analysis (DEA) and regression models, aim to identify the determinants of efficiency. This work uses a different approach represented by the use of the Malmquist index and a model of truncated regression. Through this approach, we analyze the impact of different environmental variables on the inter-annual efficiency level of the Spanish local governments, with the aim of improving the services and reaching the SDG-6. Specifically, this study analyses the impact of the following variables: Taxes, type of management, population density, level of tourism, revenues, level of income of citizens, political ideology, and political strength.

The taxes associated with the service, in addition to being an entry barrier for citizens with lower incomes, can represent a change in management and efficiency. At present, the literature has not determined a clear effect on the efficiency of municipal services. A higher tax burden may increase citizens' demands for quality services, leading to greater control of resources and improving efficiency $[26,27]$. On the other hand, those local governments that can obtain tax revenues more easily can use them without control and become less efficient [28].

The type of management represents another factor capable of influencing the efficiency of the drinking water supply. It is a fact that local governments have the ability to directly manage the provision of services related to the drinking water and sanitation, or to outsource this service to a private company. In recent years, the trend towards the privatization of services has been growing, which should lead to an increase in perceived efficiency and cost savings for citizens [20]. In this perspective, many local governments have outsourced the provision of services related to water resources in order to increase efficiency and receive a fee from private companies. However, due to differences in the excessive price paid by citizens [29] and the neglect of private companies, some local governments have returned the public management of water or sanitation services [15]. Several contributions in the literature aimed to identify which type of management (private or public) favored the efficiency of the services [30-32]. In relation to the management of drinking water supply, [17] highlighted how private management should be more efficient than public management. On the contrary, [20] found a higher level of efficiency when the drinking water provision is managed directly by the local government.

Past studies also identify population density as a determinant of efficiency in the management of water resources. However, this variable has unclear effects on the level of efficiency. Clearly, on the one hand, the water utilities that operate in areas with a high population density seem to be more efficient [17], but on the other hand, a greater density could lead to congestion problems, higher costs, and lower efficiency [33]. Empirical evidence showed mixed results. In fact, some contributions highlighted a positive effect of population density [17,21,24], others a negative effect [33], while others highlighted the absence of relations between population density and efficiency in the management of water resources [34,35].

In relation to the level of tourism, some contributions highlighted how it can influence the efficiency in the management of water services due to the overload connected with seasonal variations of the population $[24,33,36]$. This circumstance seems to concern mainly the tourist areas. However, in this regard, [37] pointed out how the high economic efficiency of coastal municipalities with high numbers of tourists connected to the higher tax revenues and the higher rate of development. However, in relation to the efficiency of water services, the results of empirical studies are conflicting. Ref [24] found a positive effect of the level of tourism on the management of water resources, while [21] did not find any significant relationship. 
The financial resources of the local governments represent another factor able to influence the efficiency in the management of public services. The results of empirical studies are conflicting. Ref [38] found a positive effect of the revenues in municipalities that improved their efficiency for the public lighting. On the contrary, [39] concluded that local governments with higher revenues are less efficient. Likewise, [40] demonstrated a negative effect of the revenues on the efficiency in the provision of public services.

The literature has also analyzed the effect of the level of citizens' income on the efficiency of water services. One part of the studies argued that a higher economic level favors the efficiency of water services [41-43]. Refs [17] and [43] found a possible explanation for improving the budgets of local governments, which can encourage investments in infrastructure capable of increasing the efficiency of water services. Refs [17] and [21] empirically studied the effect of the municipal economic level on the degree of efficiency by finding an insignificant relationship.

The impact of the political factors on the efficiency is not clear in the recent literature [26]. Many studies reached a non-significant relationship between them and the level of efficiency of the local governments $[30,44]$. Only a few studies analyzed the impact of the political factors on the efficiency in the management of water resources [20]. With reference to political ideology, [45,46] highlighted how left-wing parties are associated with a lower level of efficiency due to strong ties with public sector unions, which leads to the acceptance of wage claims and an increase in costs. With reference to political strength, $[45,46]$ stressed that it can promote greater efficiency of the local government. It is a fact that strong political leadership could more easily impose a tight budget constraint and could more easily resist union pressure. However, [26] found no significant effect of political ideology on the local government's efficiency, while [20] demonstrated a non-significant impact of political ideology and political strength in relation to the efficiency of the drinking water supply.

\section{Materials and Methods}

\subsection{Sample}

The most commonly used criterion for selecting the sample in local government research is population, subject to the available information. Consequently, the sample is formed by the Spanish municipalities with a population between 1000 and 50,000 inhabitants, which reported the input, the outputs, and the environmental variables during the period 2014-2018 (first and last of the years for which we had all the data we used in this research). Subsequently, data with numerical errors were eliminated, reducing the sample to a complete panel formed by 356 municipalities.

\subsection{Variables}

To evaluate the compliance with the SDGs, the UN has established a set of indicators with the purpose of homogenizing the calculation criteria. In our case, in order to measure the evolution of efficiency to reach SDG-6, we followed the indicators established by the UN (see Table 1) for each of the targets, adapting them to the characteristics of local governments in Spain.

To calculate the evolution of efficiency, the selection of inputs and outputs is required. Following the most recent literature measuring the efficiency of municipal services in Spanish local governments [20,47], we established as input the sum of the effective cost (Total cost) of the services corresponding to SDG-6 (drinking water supply, sewerage, and wastewater treatment). The effective cost of municipal services is determined as the algebraic sum of the direct costs associated exclusively with the service and the corresponding proportion of indirect costs. In the case of indirect management of services, the effective cost is calculated taking into account all the monetary compensations paid by the local entity to the contractor, as well as, where appropriate, subsidies to cover the price of the service. In cases of indirect management in which the contractor's remuneration is received directly from the users, the effective cost is determined by the income derived from the tariffs paid by the users, as well as, where appropriate, by the subsidies to cover the price of the service that may correspond to the local 
entity responsible for the ownership of the service (Order HAP/2075/2014 of November 6, that develops the criteria for calculating the effective cost of public services).

Table 1. Sustainable Development Goals 6: Clean water and sanitation.

\begin{tabular}{|c|c|c|}
\hline Targets $^{1}$ & Indicators $^{1}$ & Outputs $^{2}$ \\
\hline $\begin{array}{l}\text { By 2030, achieve universal and equitable access to safe and } \\
\text { affordable drinking water for all. }\end{array}$ & $\begin{array}{l}\text { Proportion of population using } \\
\text { safely managed drinking } \\
\text { water services. }\end{array}$ & $\begin{array}{l}\text { Population } \\
\text { water } \\
\text { consumption }\end{array}$ \\
\hline $\begin{array}{l}\text { By 2030, achieve access to adequate and equitable sanitation and } \\
\text { hygiene for all and end open defecation, paying special attention } \\
\text { to the needs of women and girls and those in vulnerable situations. }\end{array}$ & $\begin{array}{l}\text { Proportion of population using } \\
\text { safely managed sanitation services, } \\
\text { including a hand-washing facility } \\
\text { with soap and water. }\end{array}$ & $\begin{array}{l}\text { Population } \\
\text { sanitation } \\
\text { consumption }\end{array}$ \\
\hline \multirow{2}{*}{$\begin{array}{l}\text { By 2030, improve water quality by reducing pollution, eliminating } \\
\text { dumping and minimizing release of hazardous chemicals and } \\
\text { materials, halving the proportion of untreated wastewater, and } \\
\text { substantially increasing recycling and safe reuse globally. }\end{array}$} & $\begin{array}{l}\text { Proportion of wastewater } \\
\text { safely treated. }\end{array}$ & $\begin{array}{c}\text { Treated } \\
\text { wastewater }\end{array}$ \\
\hline & $\begin{array}{l}\text { Proportion of bodies of water with } \\
\text { good ambient water quality. }\end{array}$ & Discharge area \\
\hline $\begin{array}{l}\text { By 2030, substantially increase water-use efficiency across all } \\
\text { sectors and ensure sustainable withdrawals and supply of } \\
\text { freshwater to address water scarcity and substantially reduce the } \\
\text { number of people suffering from water scarcity. }\end{array}$ & $\begin{array}{l}\text { Change in water-use efficiency } \\
\text { over time. } \\
\text { Level of water stress: freshwater } \\
\text { withdrawal as a proportion of } \\
\text { available freshwater resources. }\end{array}$ & $\begin{array}{l}\text { Water-use } \\
\text { efficiency }\end{array}$ \\
\hline $\begin{array}{l}\text { By 2030, implement integrated water resources management at all } \\
\text { levels, including through transboundary cooperation } \\
\text { as appropriate. }\end{array}$ & $\begin{array}{l}\text { Degree of integrated water } \\
\text { resources management } \\
\text { implementation }(0-100) \text {. } \\
\text { Proportion of transboundary basin } \\
\text { area with an operational } \\
\text { arrangement for water } \\
\text { cooperation. } \\
\text { Change in the extent of } \\
\text { water-related ecosystems } \\
\text { over time. }\end{array}$ & $\begin{array}{l}\text { Central } \\
\text { government } \\
\text { responsibility } \\
\text { (River } \\
\text { Hydrographic } \\
\text { Confederation) }\end{array}$ \\
\hline $\begin{array}{l}\text { By 2030, expand international cooperation and capacity-building } \\
\text { support to developing countries in water- and sanitation-related } \\
\text { activities and programmes, including water harvesting, } \\
\text { desalination, water efficiency, wastewater treatment, recycling, } \\
\text { and reuse technologies. }\end{array}$ & $\begin{array}{l}\text { Amount of water- and } \\
\text { sanitation-related official } \\
\text { development assistance that is } \\
\text { part of a government-coordinated } \\
\text { spending plan. }\end{array}$ & $\begin{array}{l}\text { International } \\
\text { cooperation }\end{array}$ \\
\hline $\begin{array}{l}\text { Support and strengthen the participation of local communities in } \\
\text { improving water and sanitation management. }\end{array}$ & $\begin{array}{l}\text { Proportion of local administrative } \\
\text { units with established and } \\
\text { operational policies and } \\
\text { procedures for participation of } \\
\text { local communities in water and } \\
\text { sanitation management. }\end{array}$ & $\begin{array}{c}\text { Citizen } \\
\text { participation }\end{array}$ \\
\hline
\end{tabular}

For the outputs, following the indicators proposed by the UN (see Table 1), we considered the most approximate way to evaluate SDG-6 in the context of local governments with the following variables: The percentage of the population that uses the water supply service (Population water consumption), the percentage of the population that uses the sanitation service (Population sanitation consumption), the amount of wastewater treated (Treated wastewater), area where the wastewater is discharged, classified between "normal area", "less sensitive area", and "sensitive area" (Discharge area), the efficiency in the consumption of drinking water (Water-use efficiency), which has been obtained from the input of cubic meters of drinking water consumed per day and the output of the population supplied, using the DEA model with input orientation and variable returns (VRS), the current and capital transfers destined abroad (International cooperation), and citizen participation expenditures (Citizen participation). For these last two variables, given the difficulty of knowing the exact amount referring to the selected services, only the proportional part that represents the effective cost over the total expenditure has been considered. 
Table 2. Description and descriptive statistics of input, outputs, and environmental variables.

\begin{tabular}{|c|c|c|c|c|c|c|}
\hline Variable (unit) & Description & Minimum & Mean & Median & Maximum & Deviation \\
\hline \multicolumn{7}{|c|}{ Input } \\
\hline Total cost (euro) ${ }^{a}$ & $\begin{array}{l}\text { Total amount of effective cost of drinking water supply, } \\
\text { sanitation and wastewater treated }\end{array}$ & $10,021.8200$ & $580,130.7106$ & $230,570.7550$ & $7,827,156.4300$ & $972,089.7475$ \\
\hline \multicolumn{7}{|c|}{ Outputs } \\
\hline Population water consummation (\%) $)^{\mathrm{b}, \mathrm{c}}$ & Population with water supply service & 19.9846 & 99.1575 & 99.9618 & 99.9976 & 4.7182 \\
\hline Population sanitation consummation (\%) $)^{b, c}$ & Population with sewage service & 6.3853 & 95.1048 & 99.9485 & 99.9976 & 13.3867 \\
\hline Treated wastewater $\left(\mathrm{m}^{3} / \text { day }\right)^{\mathrm{b}}$ & Quantity of wastewater treated & 1.0000 & 1332.2292 & 509.7890 & 11201.9616 & 2013.8275 \\
\hline Discharge area ${ }^{b}$ & $\begin{array}{l}\text { Average classification of waste water discharge area, takes the } \\
\text { value } 3 \text { if the area is normal, } 2 \text { if it is less sensitive and } 1 \text { if it is } \\
\text { sensitive for the environment }\end{array}$ & 1.0000 & 2.5747 & 3.0000 & 3.0000 & 0.6678 \\
\hline Water-use efficiency ${ }^{d}$ & Efficiency in drinking water consumption & 0.0017 & 0.1179 & 0.0623 & 1.0000 & 0.1619 \\
\hline International cooperation (euro) ${ }^{\mathrm{e}}$ & Current and capital transfers abroad & 0.4019 & 1166.0175 & 416.2879 & $20,085.5166$ & 2072.6802 \\
\hline Citizen participation (euro) $^{\mathrm{e}}$ & Resources for citizen participation & 3.3339 & 1759.1688 & 595.2337 & 32635.9418 & 3579.3449 \\
\hline \multicolumn{7}{|c|}{ Environmental variables } \\
\hline Taxes (euro) ${ }^{\mathrm{e}}$ & $\begin{array}{l}\text { The per capita sum of the collection of tax for the supply of } \\
\text { drinking water, sewerage, and sanitation }\end{array}$ & 0.0000 & 35.9694 & 27.5539 & 344.5296 & 40.0609 \\
\hline Management ${ }^{\mathrm{a}}$ & $\begin{array}{l}\text { Sum of the type of management, variable that takes the value } 3 \\
\text { for public provision; and } 0 \text { for private, in the three services }\end{array}$ & 0.0000 & 2.3778 & 3.0000 & 3.0000 & 1.0473 \\
\hline Density (inhabitants) ${ }^{c, f}$ & $\begin{array}{l}\text { Population density of the municipality } \\
\left.\text { (Population } / \mathrm{km}^{2}\right)\end{array}$ & 2.2442 & 119.6934 & 46.1344 & 5436.1991 & 352.8484 \\
\hline Tourism $\mathrm{g}$ & Tourism index & 0.0000 & 12.2289 & 1.1459 & 392.8963 & 45.3241 \\
\hline Revenues (euro) ${ }^{\mathrm{e}}$ & Budget revenues per capita of the municipality & 536.8723 & 1097.5188 & 1016.8062 & 5108.5960 & 374.3808 \\
\hline Income (euro) ${ }^{\mathrm{g}}$ & Available family income per inhabitant & 6488.7115 & $12,001.8660$ & $10,507.6514$ & $89,395.2016$ & 8039.4610 \\
\hline Ideology ${ }^{\mathrm{h}}$ & $\begin{array}{l}\text { Political ideology of the mayor, dummy variable that takes value } \\
1 \text { conservative, value } 0 \text { for progressive }\end{array}$ & 0.0000 & 0.3574 & 0.0000 & 1.0000 & 0.4794 \\
\hline Strength ${ }^{\mathrm{i}}$ & Herfindahl index measuring local government political strength & 0.1696 & 0.4364 & 0.4321 & 1.0000 & 0.1029 \\
\hline
\end{tabular}


According to the existing literature (see Section 2), we selected a set of environmental variables that can affect the evolution of efficiency to reach SDG-6, such as: Per capita sum of the collection of fees for the supply of drinking water, sewerage, and sanitation (Taxes), type of management, differentiated between public when the local government provides the service directly, or private when it is a third party that does so (Management), population density (Density), the level of tourism activity in the municipality (Tourism), per capita revenues of the local government (Revenues), disposable income of the inhabitants of the municipality (Income), the ideology of the Mayor's party, which takes the value 1 if it is conservative and 0 if it is progressive (Ideology), and the Herfindahl index, which measures the level of fragmentation of local government (Strength). Table 2 shows the sources of information, the units of measurement, the description and descriptive statistics of the input, the outputs, and the environmental variables.

\subsection{Malmquist Index}

To measure the inter-annual change in efficiency, the Malmquist index is a suitable tool [48], which shows the evolution of efficiency according to the technological changes produced [49]. Similarly to the DEA, the Malmquist index allows the selection of multiple inputs/outputs. It does not require the definition of their prices or technological structure, being an appropriate technique for measuring the evolution of efficiency in the public sector $[38,50,51]$.

The solution of Equation (1) provides the change of efficiency in a DMU, where it improves its level in $t+1$ with respect to $t$ if $M_{i}^{t}\left(x_{i}^{t}, y_{i}^{t}, x_{i}^{t+1}, y_{i}^{t+1}\right)<1$; on the contrary, if $M_{i}^{t}\left(x_{i}^{t}, y_{i}^{t}, x_{i}^{t+1}, y_{i}^{t+1}\right)>1$, the evolution of efficiency will have decreased, and if $M_{i}^{t}\left(x_{i}^{t}, y_{i}^{t}, x_{i}^{t+1}, y_{i}^{t+1}\right)=1$, there will have been no change during the period.

$$
M_{i}^{t}\left(x_{i}^{t}, y_{i}^{t}, x_{i}^{t+1}, y_{i}^{t+1}\right)=\frac{D_{i}^{t}\left(x_{i}^{t}, y_{i}^{t}\right)}{D_{i}^{t}\left(x_{i}^{t+1}, y_{i}^{t+1}\right)}
$$

where $x_{i}^{t}, y_{i}^{t}$ represent the vector of input and outputs respectively for each DMU and period analyzed, $D_{i}^{t}\left(x_{i}^{t}, y_{i}^{t}\right)$ is the distance function of the DMU $i$ during period $t$ (taking as reference the technology of period $t)$, and $D_{i}^{t}\left(x_{i}^{t+1}, y_{i}^{t+1}\right)$ is the distance function that establishes the comparison of the productivity of the DMU $i$ during period $t+1$, with respect to the technology of period $t$.

To calculate the Malmquist index, we used the R-Studio software with the deaR package [52]. In addition to the inputs/outputs, it is necessary to select the orientation of the model between input or output and its returns. Regarding the orientation, given the input level, the second option examines the maximum proportional increase in the output vector. Therefore, we opted for the output orientation aimed at maximizing the output vector for the established input vector, i.e., to achieve the maximum possible level of the SDG-6 indicators while maintaining the resources used. Likewise, for the choice of returns, different options are offered in the literature, opting for variable returns to scale (VRS) as the most appropriate and used measure, being the safest approach [53].

\subsection{Model Regression}

In order to know the effect of environmental variables on the evolution of efficiency, we estimated the following model (2):

$$
\hat{\delta}_{i t}=\alpha+\beta_{1} \text { Taxes }_{i t} \begin{gathered}
+\beta_{2} \text { Management }_{i t}+\beta_{3} \text { Density }_{i t}+\beta_{4} \text { Tourism }_{i t} \\
+\beta_{5} \text { Revenues }_{i t}+\beta_{6} \text { Income }_{i t}+\beta_{7} \text { Ideolog }_{i t}+\beta_{8} \text { Strength }_{i t}+\varepsilon_{i t}
\end{gathered}
$$

where $\hat{\delta}_{i t}$ is the Malmquist index for each DMU and period analyzed, $\alpha$ is the model constant, $\beta_{j}$ are the coefficients, Taxes, Management, Density, Tourism, Revenues, Income, Ideology and Strength are the environmental variables for each municipality collected in the literature (see Section 2) and $\varepsilon_{i t}$ is the error term. 
We used a truncated regression model with the R-Studio software and the Truncreg package, which estimates the model for Gaussian variables truncated by maximum likelihood [54]. As in [38] or [55], we used this truncated regression model, according to the results of [56], since it provides better statistical inference than the Ordinary Least Squares (OLS), Logit or Tobit regressions do. In addition, the levels of the Malmquist index require truncation, to differentiate between local governments that improve their performance $(<1)$ and those that worsen it $(>1)$. Likewise, we checked that the assumption of separability was fulfilled [57] prior to running a second stage regression using efficiency scores. In addition, to avoid a possible correlation between the environmental variables that invalidate the estimation of the model, the correlation matrix is presented in Table 3.

Table 3. Coefficient of correlation among environmental variables.

\begin{tabular}{|c|c|c|c|c|c|c|c|}
\hline & Taxes & Managent & Density & Tourism & Revenues & Income & Ideoloy \\
\hline Management & $0.2540 * * *$ & 1.0000 & & & & & \\
\hline Density & $-0.1390^{* * *}$ & $-0.2834^{* * *}$ & 1.0000 & & & & \\
\hline Tourism & -0.0652 & $-0.0896^{* *}$ & 0.0627 & 1.0000 & & & \\
\hline Revenues & $0.1304^{* * *}$ & $0.1317^{* * *}$ & $-0.0959 * *$ & $0.2608^{* * *}$ & 1.0000 & & \\
\hline Income & -0.0664 & -0.0535 & 0.0514 & 0.0809 * & $0.0995^{* *}$ & 1.0000 & \\
\hline Ideology & -0.0070 & -0.0326 & 0.0011 & 0.0586 & 0.0015 & $0.1101^{* * *}$ & 1.0000 \\
\hline Strength & $0.1264^{* * *}$ & 0.1790 *** & $-0.1966^{* * *}$ & $-0.1403^{* * *}$ & $0.1169^{* * *}$ & -0.0578 & 0.0530 \\
\hline
\end{tabular}

\section{Results and Discussion}

In order to reach the SDG-6 targets by 2030, local governments must address major changes in the management of the services indicated. The evolution of efficiency to reach SDG-6 has been decreasing in recent years (see Table 4). In the first period analyzed (2014-2015), 63.20\% of the municipalities improved their efficiency with respect to the previous year, reducing it to $51.41 \%$ in the last period (2017-2018). The implementation of the SDGs began in 2016, the period in our sample (2016-2017) where local governments showed the worst efficiency performance.

Table 4. Descriptive statistics and results of the inter-annual efficiency.

\begin{tabular}{ccccc}
\hline & $\mathbf{2 0 1 4 - 2 0 1 5}$ & $\mathbf{2 0 1 5 - 2 0 1 6}$ & $\mathbf{2 0 1 6 - 2 0 1 7}$ & 2017-2018 \\
\hline Minimum & 0.1328 & 0.1402 & 0.1367 & 0.1935 \\
\hline 1st Qu & 0.8421 & 0.7669 & 0.6093 & 0.7555 \\
\hline Mean & 1.3546 & 1.1930 & 0.9221 & 1.1143 \\
\hline Median & 1.1506 & 1.0746 & 0.8130 & 1.0185 \\
\hline 3rd Qu & 1.5332 & 1.4176 & 1.0636 & 1.3104 \\
\hline Maximum & 9.7252 & 3.7264 & 4.4011 & 7.3956 \\
\hline Deviation & 0.9360 & 0.6369 & 0.5084 & 0.6272 \\
\hline$n$ & 356 & 356 & 356 & 356 \\
\hline Number of municipalities improve & 225 & 201 & 108 & 183 \\
\hline
\end{tabular}

One of the causes that could explain this fact is gathered in the literature referring effect of the electoral cycle on the management of municipal services. It has been confirmed that, in the pre-election years, expenditures are increased, taxes are reduced, and services are improved [58-60], negatively affecting the rest of the cycle. In the period analyzed (2014-2018), the municipal elections were held in 2015, confirming the effect of the electoral cycle on the results obtained. 
To reverse the downward trend of recent years and contribute to the achievement of SDG-6, Table 5 shows the result of the truncated model regression (2). The possible causes are then discussed. We identified the determining factors of the evolution of efficiency by grouping those municipalities that improved their evolution in the analyzed periods (Model 2.1), those that worsened (Model 2.2), and all of them (Model 2.3).

Table 5. Truncated regression results.

\begin{tabular}{cccc}
\hline & Model 2.1 & Model 2.2 & Model 2.3 \\
\hline Intercept & $1.0017 \times 10^{0}(6.2253)^{* * *}$ & $5.5957 \times 10^{-1}(6.4677) * * *$ & $2.0559 \times 10^{-2}(0.1445)$ \\
\hline Taxes & $1.7370 \times 10^{-3}(2.4648)^{* *}$ & $1.0221 \times 10^{-3}(2.3492)^{* *}$ & $4.3699 \times 10^{-3}(6.9840)^{* * *}$ \\
\hline Management & $-7.5839 \times 10^{-2}(-2.4711)^{* *}$ & $-4.0341 \times 10^{-3}(-0.2929)$ & $-8.7096 \times 10^{-2}(-3.3819)^{* * *}$ \\
\hline Density & $2.4042 \times 10^{-4}(3.2218)^{* * *}$ & $-4.0073 \times 10^{-5}(-0.9610)$ & $2.6797 \times 10^{-4}(4.0638)^{* * *}$ \\
\hline Tourism & $4.5463 \times 10^{-4}(0.7821)$ & $-1.2501 \times 10^{-4}(-0.3245)$ & $6.4199 \times 10^{-4}(1.2097)$ \\
\hline Revenues & $4.5231 \times 10^{-4}(6.4527)^{* * *}$ & $* 1.0566 \times 10^{-4}(1.8297)$ & $7.1215 \times 10^{-4}(10.8086)^{* * *}$ \\
\hline Income & $1.1523 \times 10^{-5}(3.8113)^{* * *}$ & $4.2135 \times 10^{-8}(0.0182)$ & $1.3489 \times 10^{-5}(4.8627)^{* * *}$ \\
\hline Ideology & $3.1433 \times 10^{-2}(0.4973)$ & $-1.2553 \times 10^{-2}(-0.4513)$ & $5.9949 \times 10^{-2}(1.1384)$ \\
\hline Strength & $-2.0693 \times 10^{-1}(-0.7018)$ & $2.8614 \times 10^{-1}(1.9778) * *$ & $-3.8960 \times 10^{-2}(-0.1536)$ \\
\hline \multicolumn{5}{c}{ Significance: ${ }^{* * *} 1 \%{ }^{* *} 5 \%, * 10 \%$, coefficient and (t-value). }
\end{tabular}

The evolution of efficiency in the municipalities with the highest tax burden (Taxes), referring to water supply, sewerage and sanitation services, has led to an improvement, confirming the results of [26]. These governments, by having more revenues from taxes, can use more sophisticated systems for the provision of services, and therefore, improve their efficiency. Although greater taxation means improving the evolution of efficiency, citizens with lower incomes will have greater difficulty in accessing these services. In this regard, local governments must work to balance this aspect, guaranteeing universal access for citizens.

One out of every ten euros of the municipal budget is allocated to these services, which highlights the importance of resource management. The public management appears to be less efficient than private management, consistently with the results obtained by [17]. Accordingly, local governments that provide services directly could rethink the Management model, and identify which factors cause the reduction in inter-annual efficiency and, if necessary, change the management of the service. These results are also confirmed for the group of municipalities analyzed, but not for those whose level of efficiency worsened.

The population density (Density) in the provision of these services, compulsory in the case of Spain, creates economies of scale in their management that improve efficiency. These results are in line with those obtained by [24]. In our sample, the municipalities with the highest density of population will be more efficient.

Local governments with greater financial capacity (Revenues), can manage services more efficiently due to the availability of resources. These results are consistent with the fact that a higher tax (Taxes) burden means more Revenues, and therefore, a higher level of inter-annual efficiency, and the results obtained by [38]. For the local governments analyzed, an increase in Revenues will allow them to employ more sophisticated mechanisms that improve the evolution of efficiency. On the other hand, citizens with high purchasing power (Income) will require, from their public managers, services in accordance with their living conditions. They will demand more and better services, pressing on their politicians for more efficient management, confirming the results obtained by [42]. This fact is confirmed for the set of municipalities analyzed and those that progress positively, where an increase in citizens' income improves inter-annual efficiency. 
With regard to political factors, among the local governments that worsened their inter-annual efficiency level, those with a majority in government (Strength) decline less. These majority governments can implement their policies without the need to obtain the support of other political agents, which could mean addressing other demands that will cause a reduction in efficiency [46].

Finally, for the selected sample, the tourist activity of the municipality (Tourism) has no effect on the evolution of efficiency. Such results are similar to those obtained by [21]. In addition, we confirm the literature, which suggests the loss of influence of ideology in public management (Ideology), where local governments focus on solving the citizens' needs regardless of their ideology [44].

\section{Conclusions}

Achieving the SDGs by 2030 is not an easy task. However, important steps have been taken, and one of them has been to involve local governments in the compliance process. To date, local governments represent agents of change as they hold the key to activating citizen awareness, which is an essential element in achieving the SDGs. These objectives will be better reached if the national, regional, and local planning processes in each country are structured and coordinated and if specific strategies, policies, and processes are taken into account.

This need for territorialization of SDGs makes local governments an essential element for the effective implementation of Agenda 2030, as well as a key actor for the mobilization of citizens and all stakeholders. Local governments, therefore, play an important role in achieving a particular objective, SDG-6, which aims to ensure the availability and sustainable management of water and sanitation for all.

In this sense, by using the Malmquist index, we measured the efficiency of the drinking water supply and sanitation service in an attempt to analyze the evolution in the achievement of the SDG-6 by Spanish local governments. In addition, with a truncated regression model, we identified the determinants of the inter-annual efficiency level. To do this, we used a sample composed of a complete panel of 356 Spanish municipalities for the period 2014-2018, with a population of between 1000 and 50,000 inhabitants.

To achieve SDG-6 in 2030, the factors that can improve the evolution of the efficiency of Spanish local governments are: Increasing taxes associated with water supply and sanitation services (Taxes), introducing the private management of services (Management), higher population densities (Density), increasing local governments' budget revenues (Revenues), rising the income of the inhabitants of the municipality (Income), and preventing the fragmentation of local government (Strength). This would mean: Offering more with the same inputs.

Finally, it should be noted that this research presents two limitations. The first is related to the analysis only of those municipalities that have a number of inhabitants between 1000 and 50,000, related to the limited availability of information. The second limitation has to do with the local nature of our research. It would be desirable in this respect to replicate it in other geographical areas.

However, these limitations are a starting point for future research, which may, first, extend the analysis to municipalities with a number of inhabitants of less than 1000 and 50,000 and, second, carry out comparative analyses concerning the efficiency of local governments in different countries in the management of water resources. In addition, future research will analyze the impact of other environmental variables on the inter-annual efficiency level of local governments and examine efficiency as a measure of the achievement of other SDGs.

Author Contributions: Conceptualization, P.-J.M.-C., N.R., F.V., and B.B.; methodology, P.-J.M.-C.; software, P.-J.M.-C.; validation, P.-J.M.-C., N.R., F.V. and B.B.; formal analysis, P.-J.M.-C., N.R., F.V. and B.B.; investigation, P.-J.M.-C., N.R., F.V. and B.B.; resources, P.-J.M.-C., N.R., F.V. and B.B.; data curation, P.-J.M.-C.; writing-original draft preparation, P.-J.M.-C., N.R., F.V. and B.B.; writing-review and editing, P.-J.M.-C., N.R., F.V. and B.B.; visualization, P.-J.M.-C. and N.R.; supervision, P.-J.M.-C., N.R., F.V. and B.B.; project administration, P.-J.M.-C., N.R., F.V. and B.B.. All authors have read and agreed to the published version of the manuscript.

Funding: The Spanish Ministry of Education (FPU-MEC 16/03180) has financially supported this study. 
Conflicts of Interest: The authors declare no conflict of interest.

\section{References}

1. United Nations. Transforming our World: The 2030 Agenda for Sustainable Development. 2015. Available online: https://sustainabledevelopment.un.org/content/documents/21252030\%20Agenda\%20for\% 20Sustainable\%20Development\%20web.pdf (accessed on 10 February 2020).

2. Kaur, A.; Lodhia, S.K. Sustainability accounting, accountability and reporting in the public sector. Meditari Account. Res. 2019, 27, 498-504. [CrossRef]

3. Ball, A.; Grubnic, S. Sustainability accounting and accountability in the public sector. In Sustainability Accounting and Accountability; Unerman, J., Bebbington, J., O’Dwyer, B., Eds.; Routledge: London, UK, 2007; pp. 243-265.

4. Ball, A. Sustainability accounting in UK local government an agenda for research. In Association of Chartered Certified Accountants; ACCA Research Report, No. 78; Association of Chartered Certified Accountants: London, UK, 2002.

5. Ball, A.; Grubnic, S.; Birchall, J. Sustainability accounting and accountability in the public sector. In Sustainability Accounting and Accountability; Beggington, J., Unerman, J., O’Dwyer, B., Eds.; Routledge: London, UK, 2014; pp. 176-196.

6. Narbón-Perpiná, I.; De Witte, K. Local governments' efficiency: A systematic literature review-Part I. Int. Trans. Oper. Res. 2018, 25, 431-468. [CrossRef]

7. Narbón-Perpiná, I.; De Witte, K. Local governments' efficiency: A systematic literature review-Part II. Int. Trans. Oper. Res. 2018, 25, 1107-1136. [CrossRef]

8. Nagy, J.A.; Benedek, J.; Ivan, K. Measuring sustainable development goals at a local level: A case of a metropolitan area in Romania. Sustainability 2018, 10, 3962. [CrossRef]

9. Lindoso, D.P.; Eiró, F.; Bursztyn, M.; Rodrigues-Filho, S.; Nasuti, S. Harvesting Water for Living with Drought: Insights from the Brazilian human coexistence with semi-aridity approach towards achieving the sustainable development goals. Sustainability 2018, 10, 622. [CrossRef]

10. Andres, L.; Boateng, K.; Borja-Vega, C.; Thomas, E. A Review of In-Situ and Remote Sensing Technologies to Monitor Water and Sanitation Interventions. Water 2018, 10, 756. [CrossRef]

11. Bain, R.; Johnston, R.; Mitis, F.; Chatterley, C.; Slaymaker, T. Establishing sustainable development goal baselines for household drinking water, sanitation and hygiene services. Water 2018, 10, 1711. [CrossRef]

12. Kempster, S.; Hueso, A. Moving Up the Ladder: Assessing Sanitation Progress through a Total Service Gap. Water 2018, 10, 1735. [CrossRef]

13. Ananda, J. Explaining the environmental efficiency of drinking water and wastewater utilities. Sustain. Prod. Consum. 2019, 17, 188-195. [CrossRef]

14. Byrnes, J.; Crase, L.; Dollery, B.; Villano, R. The relative economic efficiency of urban water utilities in regional New South Wales and Victoria. Resour. Energy Econ. 2010, 32, 439-455. [CrossRef]

15. Walter, M.; Cullmann, A.; Von Hirschhausen, C.; Wand, R.; Zschille, M. Quo vadis efficiency analysis of water distribution? A comparative literature review. Util. Policy 2009, 17, 225-232. [CrossRef]

16. Worthington, A.C. A review of frontier approaches to efficiency and productivity measurement in urban water utilities. Urban Water J. 2014, 11, 55-73. [CrossRef]

17. See, K.F. Exploring and analysing sources of technical efficiency in water supply services: Some evidence from Southeast Asian public water utilities. Water Resour. Econ. 2015, 9, 23-44. [CrossRef]

18. Güngör-Demirci, G.; Lee, J.; Keck, J. Measuring water utility performance using nonparametric linear programming. Civ. Eng. Environ. Syst. 2017, 34, 206-220. [CrossRef]

19. Güngör-Demirci, G.; Lee, J.; Keck, J. Assessing the performance of a California water utility using two-stage data envelopment analysis. J. Water Resour. Plan. Manag. 2018, 144, 05018004. [CrossRef]

20. Balaguer-Coll, M.T.; Brun-Martos, M.I.; Márquez-Ramos, L.; Prior, D. Local government efficiency: Determinants and spatial interdependence. Appl. Econ. 2019, 51, 1478-1494. [CrossRef]

21. De Borger, B.; Kerstens, K. Cost efficiency of Belgian local governments: A comparative analysis of FDH, DEA, and econometric approaches. Reg. Sci. Urban Econ. 1996, 26, 145-170. [CrossRef]

22. Balaguer-Coll, M.T.; Prior, D.; Tortosa-Ausina, E. On the determinants of local government performance: A two-stage nonparametric approach. Eur. Econ. Rev. 2007, 51, 425-451. [CrossRef] 
23. Benito, B.; Faura, Ú.; Guillamón, M.D.; Ríos, A.M. The efficiency of public services in small municipalities: The case of drinking water supply. Cities 2019, 93, 95-103. [CrossRef]

24. García-Sánchez, I.M. Efficiency measurement in Spanish local government: The case of municipal water services. Rev. Policy Res. 2006, 23, 355-372. [CrossRef]

25. García-Valiñas, M.A.; Muñiz, M.A. Is DEA useful in the regulation of water utilities? A dynamic efficiency evaluation (a dynamic efficiency evaluation of water utilities). Appl. Econ. 2007, 39, 245-252. [CrossRef]

26. Picazo-Tadeo, A.J.; Sáez-Fernández, F.J.; González-Gómez, F. Does service quality matter in measuring the performance of water utilities? Util. Policy 2008, 16, 30-38. [CrossRef]

27. Picazo-Tadeo, A.J.; Sáez-Fernández, F.J.; González-Gómez, F. The role of environmental factors in water utilities' technical efficiency. Empirical evidence from Spanish companies. Appl. Econ. 2009, 41, 615-628. [CrossRef]

28. Picazo-Tadeo, A.J.; Sáez-Fernández, F.J.; González-Gómez, F. Assessing performance in the management of the urban water cycle. Water Policy 2011, 13, 782-796. [CrossRef]

29. De Lázaro Torres, M.L.; Borderías Uribeondo, P.; Morales Yago, F.J. Citizen and Educational Initiatives to Support Sustainable Development Goal 6: Clean Water and Sanitation for All. Sustainability 2020, 12, 2073. [CrossRef]

30. Pérez-López, G.; Prior, D.; Zafra-Gómez, J.L. Rethinking new public management delivery forms and efficiency: Long-term effects in Spanish local government. J. Public Adm. Res. Theory 2015, 25, 1157-1183. [CrossRef]

31. Pérez-López, G.; Prior, D.; Zafra-Gómez, J.L. Temporal scale efficiency in DEA panel data estimations. An application to the solid waste disposal service in Spain. Omega 2018, 76, 18-27. [CrossRef]

32. Pérez-López, G.; Prior, D.; Zafra-Gómez, J.L.; Plata-Díaz, A.M. Cost efficiency in municipal solid waste service delivery. Alternative management forms in relation to local population size. Eur. J. Oper. Res. 2016, 255, 583-592. [CrossRef]

33. Lannier, A.L.; Porcher, S. Efficiency in the public and private French water utilities: Prospects for benchmarking. Appl. Econ. 2014, 46, 556-572. [CrossRef]

34. Marques, R.C.; Berg, S.; Yane, S. Nonparametric benchmarking of Japanese water utilities: Institutional and environmental factors affecting efficiency. J. Water Resour. Plan. Manag. 2014, 140, 562-571. [CrossRef]

35. Wibowo, A.; Alfen, H.W. Benchmarking the efficiencies of Indonesia's municipal water utilities using Stackelberg data envelopment analysis. Benchmarking 2015, 22, 588-609. [CrossRef]

36. Woodbury, K.; Dollery, B. Efficiency measurement in Australian local government: The case of New South Wales municipal water services. Rev. Policy Res. 2004, 21, 615-636. [CrossRef]

37. Cordero, J.M.; Pedraja-Chaparro, F.; Pisaflores, E.C.; Polo, C. Efficiency assessment of Portuguese municipalities using a conditional nonparametric approach. J. Product. Anal. 2017, 48, 1-24. [CrossRef]

38. Benito, B.; Guillamón, M.D.; Martínez-Córdoba, P.J. Determinants of efficiency improvement in the Spanish public lighting sector. Util. Policy 2020, 64, 101026. [CrossRef]

39. Giménez, V.M.; Prior, D. Long- and Short-Term Cost Efficiency Frontier Evaluation: Evidence from Spanish Local Governments. Fisc. Stud. 2007, 28, 121-139. [CrossRef]

40. Ashworth, J.; Geys, B.; Heyndels, B.; Wille, F. Competition in the political arena and local government performance. Appl. Econ. 2014, 46, 2264-2276. [CrossRef]

41. Deng, G.; Li, L.; Song, Y. Provincial water use efficiency measurement and factor analysis in China: Based on SBM-DEA model. Ecol. Indic. 2016, 69, 12-18. [CrossRef]

42. Barbosa, A.; Lima, S.C.D.; Brusca, I. Governance and efficiency in the Brazilian water utilities: A dynamic analysis in the process of universal access. Util. Policy 2016, 43, 82-96. [CrossRef]

43. Ma, H.; Shi, C.; Chou, N.T. China's water utilization efficiency: An analysis with environmental considerations. Sustainability 2016, 8, 516. [CrossRef]

44. Rios, V.; Pascual, P.; Cabases, F. What drives local government spending in Spain? A dynamic spatial panel approach. Spat. Econ. Anal. 2017, 12, 230-250. [CrossRef]

45. De Borger, B.; Kerstens, K.; Moesen, W.; Vanneste, J. Explaining differences in productive efficiency: An application to Belgian municipalities. Public Choice 1994, 80, 339-358. [CrossRef]

46. Borge, L.E.; Falch, T.; Tovmo, P. Public sector efficiency: The roles of political and budgetary institutions, fiscal capacity, and democratic participation. Public Choice 2008, 136, 475-495. [CrossRef] 
47. Narbón-Perpiná, I.; Balaguer-Coll, M.; Tortosa-Ausina, E. Evaluating local government performance in times of crisis. Local Gov. Stud. 2019, 45, 64-100. [CrossRef]

48. Simar, L.; Wilson, P.W. Central Limit Theorems and Inference for Sources of Productivity Change Measured by Nonparametric Malmquist Indices. Eur. J. Oper. Res. 2019, 277, 756-769. [CrossRef]

49. Malmquist, S. Index numbers and indifference surfaces. Trab. Estad. 1953, 4, 209-242. [CrossRef]

50. Aparicio, J.; Cordero, J.M.; Pastor, J.T. Productivity change of Portuguese municipalities after local reforms. Appl. Econ. Lett. 2017, 24, 878-881. [CrossRef]

51. Yin, J.; Tan, Q. Study on Urban Efficiency Measurement and Spatiotemporal Evolution of Cities in Northwest China Based on the DEA-Malmquist Model. Sustainability 2019, 11, 434. [CrossRef]

52. Coll-Serrano, V.; Bolos, V.; Benitez Suarez, R. deaR: Conventional and Fuzzy Data Envelopment Analysis. $\mathrm{R}$ package version 1.0. 2018. Available online: https://CRAN.R-project.org/package=deaR (accessed on 10 February 2020).

53. Simar, L.; Wilson, P.W. Non-parametric tests of returns to scale. Eur. J. Oper. Res. 2002, 139, 115-132. [CrossRef]

54. Croissant, Y.; Zeileis, A. truncreg: Truncated Gaussian Regression Models. R package version 0.2-5. 2018. Available online: https://CRAN.R-project.org/package=truncreg (accessed on 10 February 2020).

55. Cuadrado-Ballesteros, B.; García-Sánchez, I.M.; Prado-Lorenzo, J.M. Effect of modes of public services delivery on the efficiency of local governments: A two-stage approach. Util. Policy 2013, 26, 23-35. [CrossRef]

56. Simar, L.; Wilson, P.W. Estimation and inference in two-stage, semi-parametric models of production processes. J. Econom. 2007, 136, 31-64. [CrossRef]

57. Daraio, C.; Simar, L.; Wilson, P.W. Central limit theorems for conditional efficiency measures and tests of the 'separability'condition in non-parametric, two-stage models of production. Econom. J. 2018, 21, 170-191. [CrossRef]

58. Balaguer-Coll, M.T.; Brun-Martos, M.I.; Forte, A.; Tortosa-Ausina, E. Local governments' re-election and its determinants: New evidence based on a Bayesian approach. Eur. J. Political Econ. 2015, 39, 94-108. [CrossRef]

59. García-Sánchez, I.M.; Prado-Lorenzo, J.M.; Cuadrado-Ballesteros, B. Do progressive governments undertake different debt burdens? Partisan vs. electoral cycles. Rev. Contab. 2011, 14, 29-57. [CrossRef]

60. Klein, F.A.; Sakurai, S.N. Term limits and political budget cycles at the local level: Evidence from a young democracy. Eur. J. Political Econ. 2015, 37, 21-36. [CrossRef] 